\title{
Competencies of Midwifery Graduates in Kenya, Slovakia, Hungary and Czech Republic: Do We Want to Replace Obstetrics? (Short communication)
}

\section{Matulnikova (Ludmila Matulnikova)2, D. Kimuli (Daria Kimuli)2, M. Tvrdon (Miroslav Tvrdon)2, F. Hvizdak (Frantisek Hvizdak)2, M. Bartkovjak (Mario Bartkovjak)2 , D. Kalatova (Dagmar Kalatova)2, K. Mulama (Katherine Mulama)',2, A. Beresova (Anna Beresova)2 , A. Sabo (Anne Sabo)}

${ }^{1}$ Sisters of Mercy Maternity, Naiwasha, Kenya

\section{Original Article}

${ }^{2}$ St. Lesley College Nove Zamky \& UKF Nitra, St. Jan Neuman College, Czech Republic

${ }^{3}$ Martin Luther College, Backi Petrovec, Serbia

\section{E-mail address:}

ivica.gulasova4@gmail.com

\section{Reprint address:}

Ludmila Matulnikova

St. Lesley College

Nove Zamky

Slovakia

Source: Clinical Social Work and Health Intervention

Volume: 9

Issue: 4

Pages: $78-80$

Cited references: 3

\section{Reviewers:}

Vitalis Okoth

MPC, Nairobi, Kenya

\section{Key words:}

OBG. Midwifery.

\section{Publisher:}

International Society of Applied Preventive Medicine i-gap

CSWHI 2018; 9(4): 78 - 80; DOI 10.22359/cswhi_9_4_13 @ 2018 Clinical Social Work and Health Intervention

\section{Abstract:}

The EU and USA and some SEA countries having enough physicians, do not need to share doctor's duties/competencies, however, countries with lack of qualified doctors such as Sub-Saharan Africa (apart of 
RSA) and some places in rural Latin America need midwifes to assist with complicated births including caesarean section. (1-3) The aim of this short communication is to present competencies of midwives and nurses in various parts of the world, where Tropic team members are providing care to patients.

\section{Introduction}

Several papers have been published in recent years of the competencies of various paramedic occupations including midwifery and nursing. The EU and USA and some SEA countries are currently having enough physicians, so they do not need to divide doctor's duties and competences, however, countries with lack of qualified doctors such as Sub-Saharan Africa (apart of RSA) and some places in rural Latin America need, for example, midwives to assist with complicated births including caesarean section. The aim of this short communication is to present competences in various parts of the world where the Tropic team runs their health care projects.

\section{Methods}

Forty-one (41) Kenyan students of community health, 30 students in nursing program from Czech Republic, 31 from Slovakia and 20 from Hungary have participated on this research on competences of nurses and midwifery aid statistically compared with y2 test and Fisher's exact test. $\mathrm{P}<0,05$ were considered as significant.

\section{Results and Discussion}

As seen in Table 1, Kenyan students of community health/social work program have been significantly better informed/ showed better knowledge on competencies of midwiferies and nurses in comparison to Slovak $(\mathrm{p}<0,02)$ and Czech nursing students $(\mathrm{p}<0,01)$, or Hungarian social work students $(p<0,01)$.

These results are indicating conservativism and misknowledge of the role of nurses worldwide. (1) WHO Guidelines for paramedic treatments are for the majority of residents unknown (Tab 1.); what has been already published on $\mathrm{CEE} / \mathrm{V} 4$ health students and doctors. (2)

Table 1: Knowledge of competencies of midwives and nurses according to WHO guidelines.

\begin{tabular}{|l|c|c|c|c|c|}
\hline Countries: & HU & CZ & SK & Kenya & P \\
\hline Number of respondents & 20 & 30 & 31 & 41 & \\
\hline Type of study & Social Work & Nursing & Nursing & Community Health & \\
\hline Midwifery competencies & & & & & $* 41$ \\
\hline - Birth alone & 0 & $6^{*}$ & $6^{*}$ & $* 0.02$ \\
\hline - C section & 0 & 0 & 0 & 40 & 0.01 \\
\hline Nursing competencies & 1 & $* 1$ & 2 & $* 41$ & $* 0.01$ \\
\hline - Physical exam & 0 & 0 & 0 & 39 & 0.001 \\
\hline $\begin{array}{l}\text { - Drug prescription and/or } \\
\text { administration }\end{array}$ & & & & & $* 0.02$ \\
\hline
\end{tabular}




\section{Conclusion}

The level of education and global thinking as well as orientation in international health in students of health and social sciences in Slovakia, Czech Republic and Hungary is weak and needs improvement as well as better education in health sciences.

\section{Reference}

1. HARDY M, VANSAC P, BENCA J, PALUN M, GALLOVA A, SUSTA M et al. (2018). Demand on Non-Medical Health Professions Training: Adaptation to New Challenges of the Aging Populations (letter). Clinical Social Work and Health Intervention, 9(3), 74-75. doi:10.22359/ cswhi_9_3_11

2. BALUCHOVA B, MAMOVA A (2017) The role of implementation and communication of MANTRA Water, sanitation and hygiene program in improving public health in Odisha state (India) Neuroendocrinology Letters 38 (Suppl.1): 35-39

3. BAAS CI, JAAP J, ERWICH HM, WIEGERS TA, DE COCK TP `2015) Hutton EK Women's Suggestions for Improving Midwifery Care in The Netherlands. Birth 42:4 December 2015. 